\title{
Enhancing Employees' Performance through Organizational Care Policies in the Health Care Context
}

\author{
Andrea Tomo ${ }^{1} \&$ Lucio Todisco ${ }^{1}$ \\ ${ }^{1}$ Department of Economics, Management and Institutions, University of Naples “Federico II", Naples, Italy \\ Correspondence: Andrea Tomo, Department of Economics, Management and Institutions, University of Naples \\ "Federico II", Complesso Universitario Monte S. Angelo - Via Cinthia - 80126 Naples, Italy. Tel: 39-8167-5082, \\ E-mail: andrea.tomo@unina.it
}

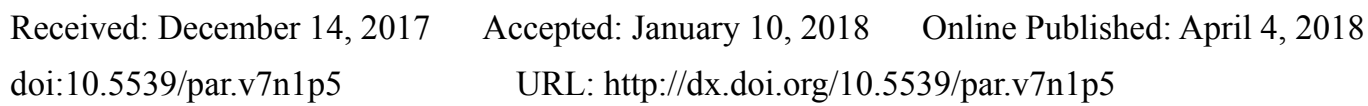

\begin{abstract}
Literature is increasingly recognizing that organizations must combine themes of care and concern with more established economic objectives. This conceptual study will expand on this literature by considering how expressions of organizational care toward employees, by improving their well-being, may influence their motivation, work involvement and, in turn, improve performance. In more detail, by extending the conceptual framework developed by Bonner \& Sprinkle (2001), it is argued that managers should take into account the impact, not only of monetary and non-monetary incentives, but even of other caring policies, on employee motivation and performance outcomes. On this ground, this study develops a theoretical model on how organizational care may help employees in expressing their work potential and enhancing their performance. The model is developed within the health care context since its particular setting that strongly affects employees' well-being.
\end{abstract}

Keywords: motivation, well-being, human resource management, health care context

\section{Introduction}

Recent literature is demonstrating a growing interest in how organizations should combine themes of care with traditional economic objectives (Rynes et al., 2012). In this regard, motivation and well-being are crucial concerns both for top managers and human resource managers, as their impact on overall organizational performance has been widely demonstrated (Foss et al., 2015; Rhoades \& Eisenberger, 2002; Riggle et al., 2009; Van de Voorde et al., 2012). On this ground, HR policies and practices in the recent past years developed new models for caring employee well-being and motivation.

With regard to organizational care for employees, managers differ considerably in how they approach and organize their employment relationships, ranging from purely contractual and transient in nature to approaches that reflect a genuine and sustained concern for employee well-being (McAllister \& Bigley, 2002; Victor \& Cullen, 1988). The balance between transactional and caring employment relationships models has always been shifted toward more transactional ones, with weakened attachments between efficiency-driven organizations and their ever more mobile workforce (Cappelli, 2008; Grant et al., 2008). In contrast to these approaches, there is the job demands-resources approach (Bakker, 2011; Bakker and Demerouti, 2007; Bakker et al., 2010; Bakker, 2015): this approach revealed that job demands, such as a high work pressure, emotional demands, and role ambiguity, may lead to sleeping problems, exhaustion, and impaired health, whereas job resources, such as social support, performance feedback, and autonomy, may instigate a motivational process leading to job-related learning, work engagement, and organizational commitment. Therefore, literature acknowledges the link among employee well-being and motivation, but what misses is the link of the antecedent to employee well-being, such as organizational policies, with employee performance.

Thus, the aim of this conceptual study is to create a connection among organizational care policies for an improved employee well-being, motivation and employee performance, asserting that care policies for employees must consider both monetary and non-monetary incentives, as they differently, but strongly, impact on well-being and motivation. On this ground, a theoretical model that links organizational care policies with well-being, motivation and performance is developed. A specific reference will be provided on the health care context since the challenges posed by this particular context, both for top managers and HR managers, to 
develop effective care policies for employees.

The paper is structured as follows. The next section discusses previous literature on motivation and well-being. The third section highlights specific factors affecting employee well-being in the health care context. The fourth section presents the theoretical framework informing the study, while the fifth presents the proposed theoretical model. The last section provides discussion and conclusions, with interesting academic and managerial implications.

\section{Previous Literature on Motivation and Well-Being}

Motivation is usually related to the job satisfaction of an employee (Herzberg, 1986; Lawler, 1973). It can be broadly defined as the willingness to exert different degrees of effort toward achieving organizational goals and satisfying existing needs (Grandori, 2001; Gruening, 2001). In addition, job satisfaction represents an important part of human activities, because people spend most of their life in a state of employment (Lut, 2012).

Motivation represents a key factor for the performance of individuals and organizations (Hornby \& Sidney, 1988). In work contest, it is possible to define motivation as the growth of employees' availability to become involved in their job activities and to increase some professional objectives, which are defined individually or organizationally (Lut, 2012; Vakkayil et al., 2017).

Generally, motivation is recognized as an important variable to be profitably adopted by health care managers. Besides, it is often weighted out through retention strategies success, including its various displays, such as intention to quit, intention to stay, recruitment, turnover, absenteeism (Kwon \& Rupp, 2013; Pankl et al., 2010).

In this paper, motivation is considered as an outcome resulting from the influence of other variables, following the job characteristic model (Hackman \& Oldham, 1976) that measures motivation through job satisfaction, absenteeism, work motivation and performance. Thus, motivation is influenced by critical psychological states affected by how job characteristics are designed (i.e. skill variety, task significance, feedback).

Indeed, motivation is connected with employees' creativity as a factor that organizations can use to innovate and stay competitive in the global marketplace. (Koseoglu et al., 2017; Liu et al., 2016).

Many theories explained the different impact of numerous factors affecting motivation. Among these, a key role is covered by the theories by Maslow (1954), Herzberg et al. (1959), Vroom (1964) and Locke et al. (1981).

Maslow (1954) theorized that five types of needs drove individual motivation: physiological, safety, belongingness and love, esteem, self-actualization. The author argued that these types of needs are strictly progressive, meaning that an individual would not pass to the next type of need without having completely satisfied the previous one. Indeed, Herzberg et al. (1959) demonstrated that also other factors may influence employee motivation, such as those determining the work environment settings. The two-factor theory (also known as Herzberg's motivation-hygiene theory) maintains that there are some factors which operate independently on job satisfaction (motivators) and on job dissatisfaction (hygienic factors). Hygienic factors create dissatisfaction if they are not present. If they are present in a job setting, dissatisfaction will be lower, but satisfaction will not be high. Motivators are related to high satisfaction and willingness to work harder. When present, these job factors may induce more effort; when absent, they would not produce dissatisfaction in most people. Motivators are associated with the content of the job.

The expectancy theory (Vroom, 1964), also known as "effort-outcome expectancy" theory, argues that individual motivation oriented to maximize expected satisfaction with outcomes is a function of two factors. First, the expectancy about the relationship between effort and a particular outcome, referred to as the. Second, the valence (attractiveness) of the outcome. The motivation created by these two factors leads people to choose a level of effort that they believe will lead to the desired outcome.

Following the goal setting approach (Locke et al., 1981), defining challenging goals rewarded by monetary incentives may boost people motivation and effort in a certain work task that they would not do otherwise. Such an effect has been never captured by other motivation theories, that differently from the goal setting theory consider the goal definition as taken for granted and well-specified in advance. Additionally, according to the goal setting view, monetary incentives may result in higher goal commitment (and thus greater effort) than non-contingent incentives or no incentives.

However, in literature, a central role within the debate on motivation has always been covered by financial incentives. Usually, starting with the analysis that money change the performance of people about cost-benefits, large monetary incentives or prizes are considered potential factors to increase employees' work motivation (Hammermann \& Mohnen, 2014). However, if there are contrasting evidences of their influence on employee 
motivation. In fact, while monetary incentives are sometimes recognized as a priority (Shortell \& Kaluzny, 2006; Singh et al., 2015) there are studies providing results showing that financial incentives are associated to negative effects or with intrinsic motivation reduction after extrinsic motivation elicitation or that in firms is necessary to realize an incentive mix to achieve a best employees' motivation (Frey, 1997; Frey \& Jegen, 1999; Kvaløy et al., 2015; Woolhander et al., 2012).

Historically, policy makers often rely upon the use of financial incentives. Here the underlying reason is that many health sector reform programs take for granted that money is a key motivator in the work context (Franco et al., 2002). There is, however, a debate on the prospects for and effectiveness of performance-related pay in public sector contexts (Bajorek and Bevan, 2015): it is impossible to draw univocal conclusions about the positive or negative effect of the financial lever on both motivation and performance. Financial incentives alone cannot resolve motivation problems, although they should be factors that decisively influence workers motivation. On this ground, it seems clear that managerial strategies and HR policies mainly relying upon financial incentives could also engender undesired effects on employee motivation (Christianson et al., 2006; Woolhander et al., 2012). Rather, since workers may overestimate financial rewards compared to other types of reward, the prospect of reaching monetary rewards could be perilously placed by personal interests before the achievement of organizational goals in health care or, in general, public service provision (McDonald et al., 2007).

Many authors (e.g., Hibbard et al., 2003; Kolstad, 2011) have highlighted the crucial impact of other non-monetary factors on motivation (e.g., reputation and learning). According to Franco et al. (2002), resource availability and worker competence are necessary but not sufficient to ensure desired organizational performance. The authors consider many motivational factors operating at the individual level in health care workers, such as organizational goals, the ability to mobilize personal resources, and organizational citizenship behavior. According to their origins, determinants can be based at the individual level, at the immediate organizational context level and at the cultural context level.

Other authors (e.g. Kuvaas et al., 2017; Lau et al., 2014) have analyzed a strict connection between non-monetary factors and an increase of employees' participation in target setting. If employees receive by management a positive feedback in target setting, organizations have a tangible increase of corporate and individual well-being (Kuvas et al., 2017).

Non-monetary factors how important management method. According to Schmidt et al. (2017), the increasing of firms' number in the global economies have reduced the possibility to use monetary incentives to assign monetary resources other investments. Firms' administrators and public managers have a key role to increase motivation and aptitude of employees to have better job performance not only with non-monetary incentives but also with care policies. (Apak \& Gümüş, 2015).

Individual level determinants are recognized in individual goals, self-concept, expectations, and experience of outcomes, that are in turn coupled with worker's technical and intellectual ability to perform and with the physical available resources. Organizational level dimensions are individuated in organizational structures, resources, processes, and culture, as well as organizational feedback on performance, as contributing to the individual motivational processes. Finally, cultural and community level determinants are mainly individuated in the relationship between organizational functioning and societal culture, and in the effect of the interactions and links with assisted patients on professionals' behavior (Franco et al., 2002).

Given the importance of the context, it is clear that also reforms in the health sector may play a critical role in affecting the different organizational levels (the whole system, the single organization, and the individuals within the organization). For instance, employee motivation may be affected by how health sector policy makers design reforms, since they could have differential impacts on the health work settings (Franco et al., 2002).

On this ground, scholars are increasingly devoting their attention to understand how organizational care policies must develop to improve employee well-being, motivation and, in turn, performance.

In fact, there is a greater understanding of the what and how of caring organizations and its implications for employees' attitudes and behaviors (e.g., Eisenberger, et al., 2001; Eder \& Eisenberger, 2008; Lee \& Miller, 1999; Miller \& Lee, 2001; Rynes et al., 2012).

Organizational care captures a wide assortment of practices and policies centered on promoting employee well-being (e.g., fair procedures, job security, employee support programs, compassionate treatment), and accumulated evidence points to its largely favorable effects on various employee outcomes and firm performance (Rhoades \& Eisenberger, 2002; Riggle et al., 2009; Van de Voorde et al., 2012). However, much remains to be 
done in understanding the link between organizational care and employee outcomes, as well as in clarifying the potential darker sides of caring practices and policies.

On this point, a key discussion concerns the process of goal and standard setting, measurement and comparison, evaluation and feedback for corrective actions related to the care policy design. In setting policies for employees' motivation, four core control mechanisms have to be taken into account by HR managers, as the way in which they are set will impact on employees' behaviors, motivation, and well-being: planning, measurement, feedback, and evaluation reward elements (Armstrong \& Taylor, 2014).

According to Flamholtz et al. (1985), planning concerns the setting of work goals and their standards for each key functional area. This control mechanism allows to enhance goal congruence between individuals and their organizations and it represents an ex ante form of control, since it produces the information needed to guide individual or collective behavior.

Measurement concerns the way in which activities are measured according to rules and standards. This might influence work behavior with the information produced as well as with process of measurement (Flamholtz, 1979). This mechanism is both a form of ex post and an ex ante control, respectively through its informational function and its behavioral or process function.

Indeed, the feedback element refers to information regarding employees' behavior and work outcomes. This mechanism is useful to provide the information needed for corrective action and to motivate employees, serving as a promise for future rewards. In doing this, feedbacks can control the work behavior of organizational members either in a directional or motivational way (Dobre 2013; VandeWalle et al., 2000).

Finally, the evaluation-reward element represents a form of ex post control. It consists in the assessment of individual or collective performance based on pre-established goals and standards. Evaluations are assessed through the information gathered by the measurement system and the direct observation of managers. Rewards are outcomes of behavior which are desirable to a person and which can be either extrinsic or intrinsic (Flamholtz et al., 1985; Ryan R. \& Deci, 2000).

In this direction are all the increasing studies relying on the job demands-resources (JD-R) model (Bakker and Demerouti, 2007; Demerouti \& Bakker, 2011; Demerouti et al. 2001). This theory helps to understand, explain, and make predictions about employee well-being (e.g. burnout, health, motivation, work engagement) and job performance. According to the theory, all working environments or job characteristics can be modeled using two different categories, namely job demands and job resources. "Job demands refer to those physical, psychological, social, or organizational aspects of the job that require sustained physical and psychological (cognitive and emotional) effort or skills and are therefore associated with certain physiological and/or psychological costs" (Demerouti \& Bakker, 2011 p. 2).

These job characteristics clearly affect employee motivation in two opposite ways. While job resources are related to positive physical, psychological, social, or organizational aspects of the job, job demands are related to those negative aspects of the job that undermine an individual physical and psychological (cognitive and emotional) condition. The presence of job resources is fundamental to achieve work goals and buffer job demands negative effects, by stimulating personal growth, learning, and development (Bakker, 2011; Bakker \& Demerouti, 2007).

\section{Specific Factors Affecting Employee Well-Being in the Health Care Context}

Well-being in the workplace has been found to have a great impact on employee performance and, more generally, on organizational performance (Rhoades \& Eisenberger, 2002; Riggle et al., 2009; Van de Voorde et al., 2012).

With reference to the specific health care context, along with other factors generally acknowledged to affect employee well-being, other specific factors are found to negatively affect employee well-being (Tomo and De Simone, 2017). Previous literature that analyzed well-being in the health care context is summarized as follows in Table 1. 
Table 1. Factors negatively influencing well-being of healthcare workers

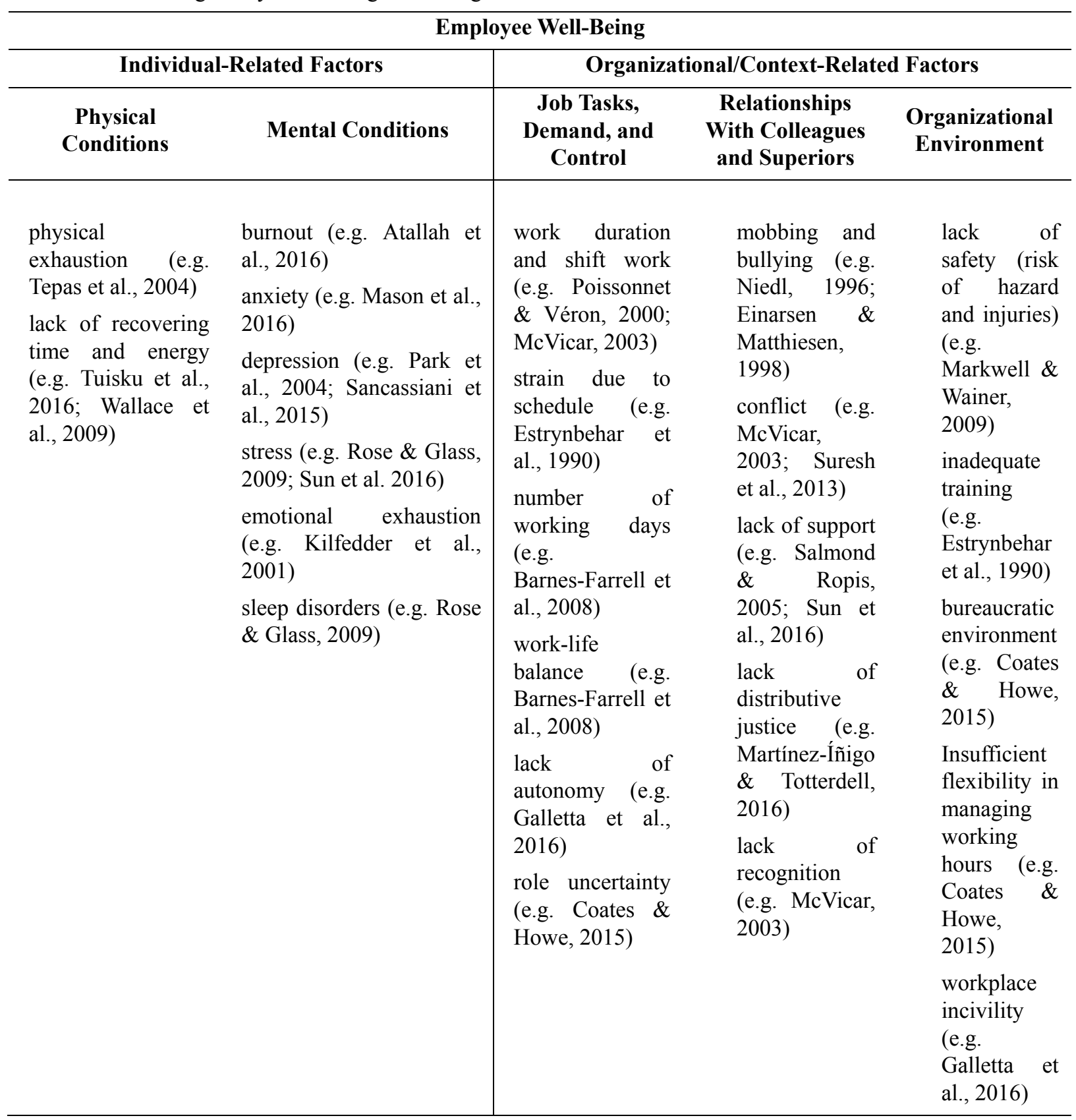

Source: Tomo and De Simone (2017)

On the individual side, many authors (Gosseries et al., 2012; Kilfedder et al., 2001; Mason et al., 2016; Preposi Cruz, 2016; Sancassiani et al., 2015; Tepas et al., 2004; Tuisku et al., 2016) highlighted several physical and mental conditions/factors that influence well-being, with a particular emphasis on physical exhaustion, anxiety, depression, stress, and burnout. Sleep disorders comprise the factor that is specifically highlighted with respect to healthcare workers (Poissonnet \& Véron, 2000; Rose \& Glass, 2009), especially considering the effects of night shift-work and difficult work schedules. Some authors underlined the role of leisure activities and other off-job experiences in buffering the negative effects of the reported factors (Tuisku et al., 2016), since an improved general quality of life may positively affect employee well-being (Preposi Cruz, 2016).

On the organizational/context side, a number of authors (Barnes-Farrell et al., 2008; de Jonge et al., 2008; d'Ettorre \& Greco, 2016; Einarsen \& Matthiesen, 1998; Estrynbehar et al., 1990; Galletta et al., 2016; Jakobsen et al., 2015; Markwell \& Wainer, 2009; McVicar, 2003; Niedl, 1996; Nixon et al., 2015; Park et al., 2004; Salmond \& Ropis, 2005; Sun et al., 2016; Suresh et al., 2013; A. Yildirim \& D. Yildirim, 2007) highlighted the 
relevance of mobbing, conflicts, by lack of rewards and recognition superiors, work demands, work duration, difficulty in balancing work and family commitments, and work context factors.

Other authors examined particularly interesting aspects, such as bureaucratic environments (Coates \& Howe, 2015; Salmond \& Ropis, 2005), the discrepancy between ideal and real work (Coates \& Howe, 2015), risk of hazard and injuries related to workers' safety (Markwell \& Wainer, 2009), shift-work (Barnes-Farrell et al., 2008; McVicar, 2003; Tepas et al., 2004). Furthermore, another interesting aspect is the employees' perception of supervisors' psychological distress that influences the individual well-being and the supervisors with hostile verbal and non-verbal behaviors against employees reduce the corporate performance. (Mathieu et al., 2014; 2016).

Coates and Howe (2015), in terms of bureaucratic aspects, explained that instances in which staff report administrative issues as their primary concern reflect a contrasting nature of the work; this may conflict with the nurses' professional status while experiencing bureaucratic paperwork or other tasks as activities with which to recover emotional energies when they are feeling the strain of emotional labor.

The risks of hazard and injuries are particularly related to the perception of safety while working (Markwell \& Wainer, 2009; Nixon et al., 2015); this is particularly true for the healthcare context since doctors and nurses are constantly in contact with patients that may suffer from different diseases.

Shift-work can influence the three following aspects: the conflict between work-to-family and social life, physical well-being, and mental well-being (Barnes-Farrell et al., 2008; McVicar, 2003; Tepas et al., 2004). These aspects are particularly emphasized in cases of night shift-work (Tepas et al., 2004), with a reported higher health risk, as it produces symptoms that correspond closely to those of mild or moderate distress (McVicar, 2003).

Again, among organizational aspects affecting well-being, it is of interest to note Suresh et al.'s (2013) conclusions regarding inadequate preparation and training: In their study, the authors analyzed stress and stressors among nurses and found that, in particular, nurses felt inadequately prepared in terms of clinical skills, knowledge, and emotional bearing.

More generally, relevance is placed on social aspects due to the great amount of time healthcare workers spend at work with their colleagues, in 12- or 24-hour shifts, sometimes combined, thus leading nurses and doctors to work for 36-48 hours consecutively. In fact, social relationships may undermine individual well-being, considering such aspects as mobbing, bullying, and uncivil behaviours from colleagues and superiors (Einarsen \& Matthiesen, 1998; Galletta et al., 2016; Niedl, 1996; A. Yildirim \& D. Yildirim, 2007).

Social aspects also represent a solution to the main causes of employee malaise: positive workplace relationships reduce turnover and the risks to adverse events at work and, in the health system, can improve the quality of care. In contrast, negative workplace relationships increase employees' turnover and can reduce the quality of care. (Ray-Sannerud et al., 2015). Many authors have underlined the importance of creating work environments that encourage employees to openly express their emotions to colleagues and managers and of offering training sessions on emotionally demanding work to make employees and managers more conscious about managing emotions (Coates \& Howe, 2015); again, Jakobsen et al. (2015) found that social relationships and psychological well-being benefit from organized physical exercises at the workplace, since such exercises represent a social experience shared by employees. A positive work environment can help to improve outcomes by creating a positive perception of how processes are made, reducing work stress, and encouraging innovations as a response to environmental and organizational change (De Simone, 2014; Neal et al., 2000; Nielsen \& Randall, 2012).

The goal-sharing by organizational members engenders a positive climate that serves to increase organizational identification and to develop stronger relationships in the organization that in turn foster higher levels of organizational growth and performance (De Simone, 2014; Glisson, 2015; Tsai, 2011).

Positive emotions engender social interactions: The emotional climate has important consequences for individual employees and for the organization as a whole. Organizational norms and the constructive use of emotion management are essential for developing and maintaining an emotional climate that enables individual well-being (Glisson, 2015). In addition, to increase a positive emotional climate in organizations, management must have a continuous communication with employees. These is a crucial point during times of organizations' change to reduce negative emotions as fear and anger in employees and to maintain a stable employees' well-being (De Simone, 2013a, 2013b; Kaplan et al., 2014).

Psychological capital (e.g. optimism, hope, and resilience) favorably influences employee attitudes, behaviors, and organizational change, especially through positive emotions. Cognitions fostered by positive emotions such 
as gratitude and appreciation contribute to increased organizational identification. When employees work together, they can encourage new ideas, share goals, and generate learning. Gratitude motivates and reinforces social actions, in both the giver and receiver of help, by inspiring positive actions. When an organization continues to cultivate a positive emotional climate, it will derive benefits from an increase in the strength of interpersonal relationships (De Simone, 2014; Glisson, 2015; Nielsen \& Randall, 2012).

Thus, in developing HR policies, managers (health care managers, in this case) have to take clear in their mind the need to help employees in coping with these factors, by the fact that they may negatively impact on employee well-being and performance.

\section{Theoretical Framework}

This work moves from the conceptual framework developed by Bonner \& Sprinkle (2001). The framework, shown in Figure 1, states that there is a link among monetary incentives, employees' effort and task performance, with impact also on motivational and cognitive mechanisms. Within this framework, an important role is also played by personal variables, task variables, environmental variables and incentive scheme variables.

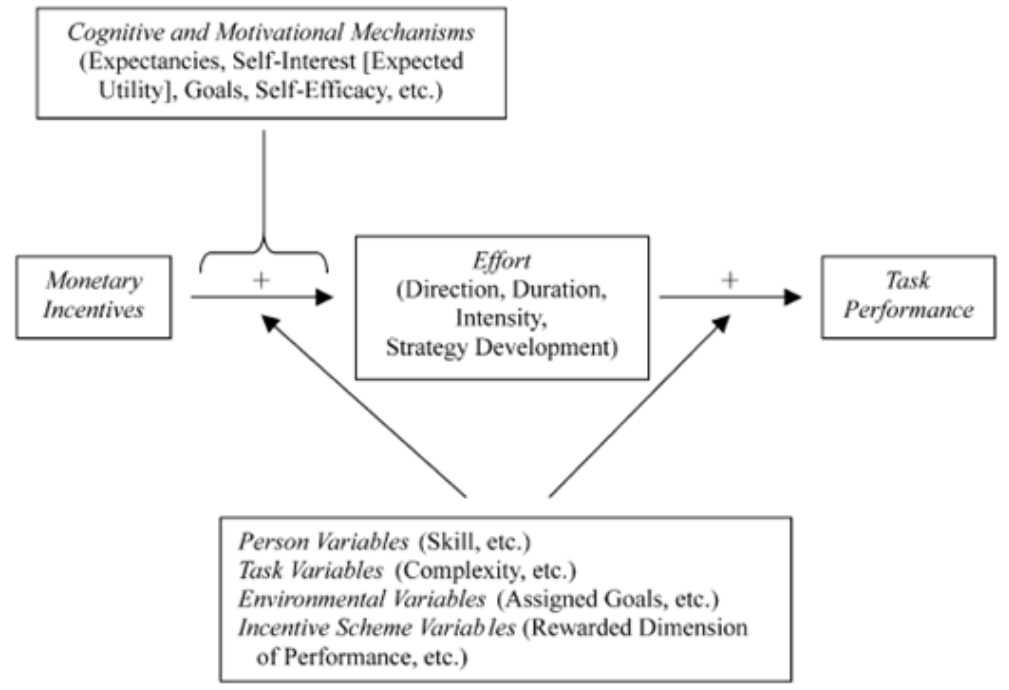

Figure 1. The conceptual framework developed by Bonner \& Sprinkle (2001)

The framework proposed by Bonner \& Sprinkle (2001) interestingly debates that a positive overall relation between the presence of monetary incentives and task performance is that incentives increase effort and increased effort leads to improvements in performance (either in the short run or the long run). In the first step, from monetary incentives to improved effort, the model highlights that a number of cognitive and motivation mechanisms, based on expectancies, self-interest, goal setting, and self-efficacy, intervene to increase employees' effort. Along with these mechanisms, other variables are proved by the authors to have influence on the process: person variables, task variables, environmental variables, and incentive scheme variable.

According to Bonner \& Sprinkle (2001), a person possesses some attributes yet prior to performing a task, such as knowledge content, knowledge organization, abilities, confidence, cognitive style, intrinsic motivation, cultural values, and risk preferences. Since person variables may vary from person to person, they can affect individual performance in different ways. For instance, they might affect the cognitive processes behind individual reasoning and evaluation on the importance of incentives, thus altering the effects of monetary incentives on performance. Personal skills are factors that people consider when assessing their self-efficacy, and when judging their capabilities for performing a specific task, thus playing an important role in a person's choice to perform a task or job, or even work for a particular firm.

Task variables include factors that vary both within and across tasks, such as complexity, effort-sensitivity, and framing. For instance, task complexity can decrease current effort duration and effort intensity, which can lead to decreases in performance.

Environmental variables include all the factors, characteristics, and conditions determining the work environment setting, such as time pressure, accountability relationships, assigned goals, and feedback. As will be 
later discussed, the work environment plays a critical role in effectively affecting employee motivation, not only as in Herzberg's view (motivating or hygiene factors), but also in terms of positive or negative organizational climate in a broader sense.

Finally, incentive scheme variables include all the characteristics related to the type of incentives and how they are structured. For instance, they might be the timing of the incentive, whether it embodies competition, what dimensions of performance the incentive rewards, and payoff magnitude. According to Bonner \& Sprinkle (2001), incentives serve a role in motivating high levels of effort and are posited to serve an informational role and, thus, are thought to be important in directing employees' effort toward their various responsibilities.

However, despite their demonstrated key role in enhancing employee motivation and effort in some cases, monetary incentives have also been found in other cases to have no impact or negative impact (e.g., Bonner et al., 2000; Camerer \& Hogarth, 1999; Jenkins et al., 1998; Guzzo et al., 1985; Prendergast, 1999). This because an higher effort is also necessarily boosted by other kinds of incentives and caring policies.

This means that, in finding solutions for increasing employee' motivation, managers should design policies that also provide non-monetary incentives and that consider to improve the work environment and climate, through promoting teamwork, team building, employees' creativity and innovation, and finding solutions to let employees managing at their best work-life balance.

On this ground, within this paper, Bonner \& Sprinkle's (2001) framework is extended also considering non-monetary incentives and other kinds of organizational care policies that may enhance a better work environment and climate that, in turn, may improve employee well-being, motivation, and performance. The next section provides in detail the description of the proposed model.

\section{A Theoretical Model for Understanding the Link among Care Policies, Well-Being, Motivation, and Performance}

There is an important relationship between well-being strategies and human resources management in order to optimize available resources and to preserve and to increase employees' motivation (Vakkayil et al.2017). The attention of management on employees' well- being is an important element because a poor well-being of employees can pose risks to reduce the quality of performance such as a less productive and fewer quality decisions. (Gilbreath \& Benson, 2004; Zakaria et al., 2014). For these reasons, organizational care policies are a central topic for management that is assessed about the capacity of fulfilling the employees' well-being. (Sebastiano et al. 2017).

Starting on the premises given by the model developed by Bonner \& Sprinkle (2001), and even acknowledging that many authors included in their frameworks both monetary and non-monetary incentives, in this paper it is argued that in addition to these incentives, also other organizational caring policies should be taken into account.

As discussed above, the health care context suffers of specific conditions that negatively affect employee well-being, in addition to other conditions generally acknowledged to the work environment. For instance, specific conditions in the health care context are night shift-works, lack of safety due to the risk of injuries and hazardous conditions related to patients' diseases, difficulties in balancing work-life time, etc.

In Table 1, the factors affecting employee well-being in the health care context have been resumed based on reviewed studies on the specific theme. In finding solutions for improving employees' well-being, all these conditions should be considered by health care managers in designing caring policies.

On this basis, the proposed model considers three specific organizational care policies based on:

1) monetary incentives: e.g., productivity bonuses;

2) non-monetary incentives: e.g., policies designed to improve employees' self-esteem, through the assignment of responsibilities;

3) other policies with the aim to improve employee well-being, different from monetary and non-monetary incentives, e.g., to improve workplace climate, reduce bullying and mobbing, help employees in balancing work-life time and copying with work-related stress, anxiety and burnout. 


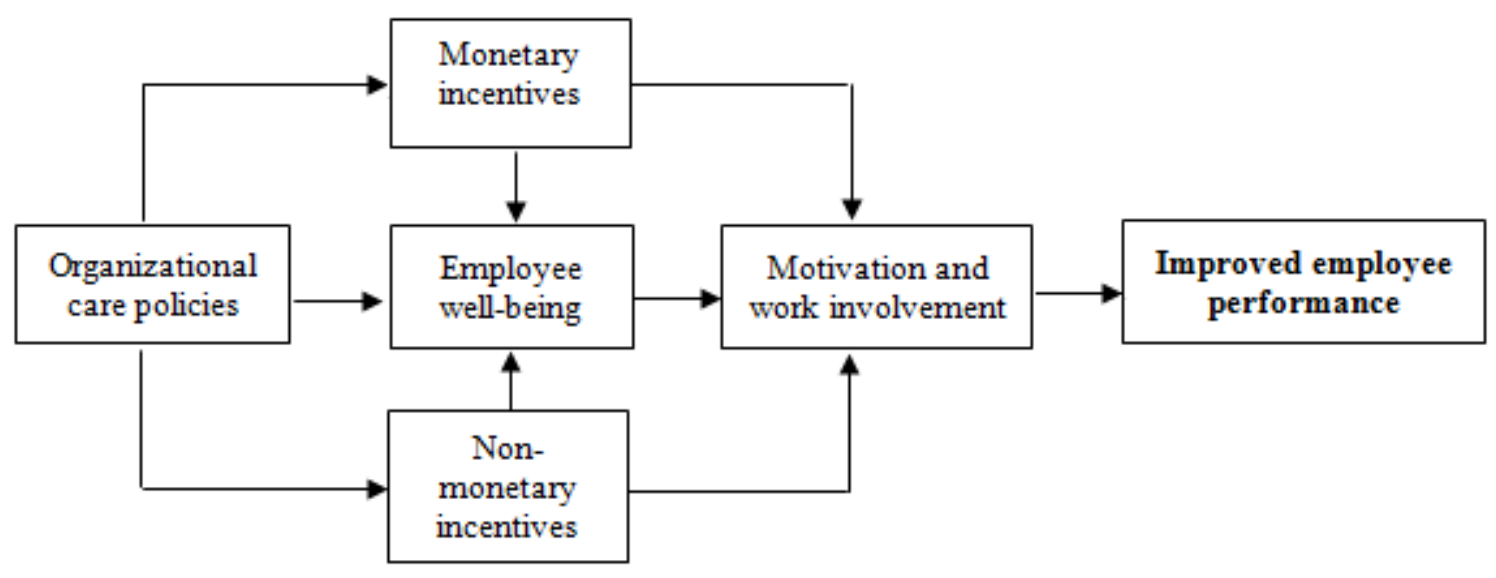

Figure 2. Proposed model for understanding the link among care policies, well-being, motivation and performance

The assumption behind this model is that monetary and non-monetary incentives do motivate employees, but also that motivation is amplified when, in addition to the incentives, organizational care policies are designed to improve also employee well-being. Organizational care policies can improve employee well-being because in according to Vakkayil et al. (2017) is possible identify three dimensions that build it: i) a psychological dimension, ii) a physical and health dimension, iii) a social well-being dimension linked to a workplace climate and the quality of relationship at work.

This is particularly true considering that, in the long run, monetary and non-monetary incentives might no longer be motivating factors (as, e.g., in Herzberg's view). Indeed, organizational care policies intervene as a support to the incentive system and to enhance employee well-being and improve the conditions to have a higher level of employees' security at work and in their personal lives and a growth of well-being in organizations (Sebastiano et al., 2017). Well-being, in turn, generates and sustains organizational citizenship behaviors and a higher effort, thus leading employees to feel more involved in the organizational life and to be a part of the organization.

In doing this connection, the proposed model integrates the view monetary and non-monetary incentives play a key role in motivating employees, with the fact that motivation itself should be boosted by specific caring policies devoted to improve employee well-being. In fact, combining well-being and motivation allows organizations to make employees feel totally involved in their working context. There is an overlap of individual and organizational expectations thus leading employees toward an improved performance. In the opposite case, when lack the union between well-being and motivation of employees is more difficult to obtain or maintain better performance in organizations (Lut, 2012).

\section{Discussion and Conclusions}

This conceptual study aimed at providing a possible theoretical model concerning the link between care policies, well-being, motivation, and performance. The proposed model extends the conceptual framework developed by Bonner \& Sprinkle (2001), where only monetary incentives have been considered in increasing employee efforts toward improved task performance. By reviewing the literature on motivation, a recent orientation toward non-monetary incentives clearly emerges, since it has been highlighted that financial incentives produce contrasting effects on employee work behavior. Again, the simple integration of monetary and non-monetary incentives is certainly a critical aspect, but not sufficient for an effective work setting. Indeed, monetary and non-monetary incentives do not include aspects such as policies oriented to improve the well-being through better condition of the work setting, both physical and psychological. In this regard, episodes such as mobbing and bullying might engender a negative climate, that will negatively affect motivation, well-being, and employee performance outcomes.

On this ground, organizational care policies have a key role in improving employees' performance through the promotion of policies devoted to enhance employee well-being through an improved work setting. In more detail, it is argued that motivation and work involvement are boosted when organizational care policies increase employee well-being. Thus, the proposed model considers the impact, not only of monetary and non-monetary 
incentives, but even of other caring policies, on employee well-being, motivation, work involvement, and performance outcomes.

With a specific reference to the health care context, it is argued that organizational care policies assume a prominent relevance with regard to the physical and psychological demanding setting characterizing the context.

This paper has manifold interesting academic, managerial, and policy implications. First, it contributes to the literature on well-being and motivation in the health care context. Second, this study reviews specific factors affecting well-being in the health-care context (see Table 1). Third, the study proposes an integrated theoretical model that puts together three relevant dimensions (monetary incentives, non-monetary incentives, and organizational care policies) and shows how these variables impact on employee well-being, motivation, and performance.

Under the managerial point of view, detecting which factors may negatively impact on employee well-being represents a key point useful to design effective HR policies to limit or avoid employees' de-motivation, alienation, absenteeism, etc. Finally, the paper has policy implication, since health policy makers could include these considerations when designing reforms concerning the health care work setting.

Future research might consider to test an empirical confirmation to the theoretical model proposed.

\section{References}

Apak, S., \& Gümüş, S. (2015). A research about the effect of the leadership qualities of public administrators on the motivation of the employees. Procedia - Social and Behavioral Sciences, 210, 368-377. https://doi.org/10.1016/j.sbspro.2015.11.384

Armstrong, M., \& Taylor, S. (2014). Armstrong's Handbook Of Human Resource Management Practice (13th ed.). UK, Ashford Colour press Ltd.

Atallah, F., McCalla, S., Karakash, S., \& Minkoff, H. (2016). American Journal of Obstetrician Gynecology, 215(6). https://doi.org/10.1016/j.ajog.2016.08.029

Bajorek, Z. M., \& Bevan, S. M. (2015). Performance-related-pay in the UK public sector: A review of the recent evidence on effectiveness and value for money. Journal of Organizational Effectiveness: People and Performance, 2(2), 94-109. https://doi.org/10.1108/JOEPP-03-2015-0011

Bakker, A. B. (2011). An evidence-based model of work engagement. Current Directions in Psychological Science, 20, 265-269. https://doi.org/10.1177/0963721411414534

Bakker, A. B. (2015). Towards a multilevel approach of employee well-being. European Journal of Work and Organizational Psychology, 24(6), 839-843. https://doi.org/10.1080/1359432X.2015.1071423

Bakker, A. B., \& Demerouti, E. (2007). The Job Demands - Resources model: state of the art. Journal of Managerial Psychology, 22, 309-328. https://doi.org/10.1108/02683940710733115

Bakker, A. B., Van Veldhoven, M. J. P. M., \& Xanthopoulou, D. (2010). Beyond the demand-control model: thriving on high job demands and resources. Journal of Personnel Psychology, 9, 3-16. https://doi.org/10.1027/1866-5888/a000006

Barnes-Farrell, J. L., Davies-Schrils, K., McGonagle, A., Walsh, B., Milia, L. D., Fischer, F. M., \& Tepas, D. (2008). What aspects of shiftwork influence off-shift well-being of healthcare workers? Applied Ergonomics, 39(5), 589-596. https://doi.org/10.1016/j.apergo.2008.02.019

Blau, P. (1964). Exchange and Power in Social Life. New York: Wiley.

Bonner, S. E., \& Sprinkle, G. B. (2002). The effects of monetary incentives on effort and task performance: theories, evidence, and a framework for research. Accounting, Organizations and Society, 27, 303-345. https://doi.org/10.1016/S0361-3682(01)00052-6

Bonner, S. E., Hastie, R., Sprinkle, G. B., \& Young, S. M. (2000). A review of the effects of financial incentives on performance in laboratory tasks: implications for management accounting. Journal of Management Accounting Research, 13, 19-64. https://doi.org/10.2308/jmar.2000.12.1.19

Camerer, C. F., \& Hogarth, R. M. (1999). The effects of financial incentives in experiments: a review and capital-labor-production framework. Journal of Risk and Uncertainty, 19, 7-42. https://doi.org/10.1023/A:1007850605129

Cappelli, P. (2008). Employment Relationships: New Models of White-collar Work. New York: Cambridge University Press. https://doi.org/10.1017/CBO9780511611544 
Christianson, J. B., Knutson, D. J., \& Mazze, R. S. (2006). Physician pay-for-performance. Implementation and research issues. Journal of General Internal Medicine, 21(S2), S9-13.

Coates, D. D., \& Howe, D. (2015). The design and development of staff wellbeing initiatives: Staff stressors, burnout and emotional exhaustion at Children and Young People's Mental Health in Australia. Administration and Policy in Mental Health and Mental Health Services Research, 42(6), 655-663. https://doi.org/10.1007/s10488-014-0599-4

De Simone, S. (2013a). Clima organizzativo come percezione del work environment [Organizational climate as perception of the work environment]. In M. Franco \& S. De Simone (Eds.), Il comportamento organizzativo nelle strutture sanitarie: relazioni interpersonali e valorizzazione delle persone (pp. 33-58). Milan: McGraw-Hill.

De Simone, S. (2013b, May). Organizational climate and organizational behavior. Paper presented at the XIV Workshop of Organizational Behavior of Professor and Researchers, Rome.

De Simone, S. (2014). The affective component of workplace in organizational behavior studies. American International Journal of Contemporary Research, 4(9), 38-43. Retrieved from http://www.aijcrnet.com/journal/index/797

Demerouti, E., \& Bakker, A. B. (2011). The Job Demands-Resources model: Challenges for future research. $S A$ Journal of Industrial Psychology/SA Tydskrif vir Bedryfsielkunde, 37(2), 1-9. https://doi.org/10.4102/sajip.v37i2.974

Demerouti, E., Bakker, A. B., Nachreiner, F., \& Schaufeli, W. B. (2001). The Job Demands - Resources model of burnout. Journal of Applied Psychology, 86, 499-512. https://doi.org/10.1037/0021-9010.86.3.499

Dobre, O. (2013). Employee motivation and organizational performance. Review of Applied Socio- Economic Research, 5(1), 53-61.

Eder, P., \& Eisenberger, R. (2008). Perceived organizational support: Reducing the negative influence of coworker withdrawal behavior. Journal of Management, 34, 55-68. https://doi.org/10.1177/0149206307309259

Einarsen, S., \& Matthiesen, S. B. (1998). Bullying, burnout and well-being among assistant nurses. Journal of Occupational Health and Safety - Australia and New Zealand, 14(6), 563-568.

Eisenberger, R., Armeli, S., Rexwinkel, B., Lynch, P., \& Rhoades, L., (2001). Reciprocation of perceived $\begin{array}{llllll}\text { organizational support. Journal of Applied Psychology, } & 86, & 42-51 .\end{array}$ https://doi.org/10.1037/0021-9010.86.1.42

Estrynbehar, M., Kaminski, M., Peigne, E., Bonnet, N., Vaichere, E., Gozlan, C., ... Giorgi, M. (1990). Stress at work and mental-health status among female hospital workers. British Journal of Industrial Medicine, 47(1), $20-28$.

Farh, J., Hackett, R., \& Liang, J. (2007). Individual-level cultural values as moderators of perceived organizational support-employee outcome relationships in China: Comparing the effects of power distance

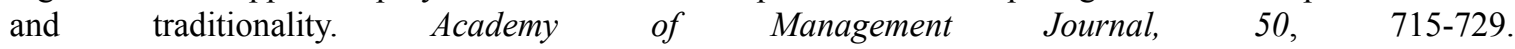
https://doi.org/10.5465/AMJ.2007.25530866

Flamholtz, E. G. (1979). Toward a Psycho-technical Systems Paradigm of Organizational Measurement. Decision Sciences, 10(1), 71-84. https://doi.org/10.1111/j.1540-5915.1979.tb00008.x

Flamholtz, E. G., Das, T. K., \& Tsui, A. S. (1985). Toward an integrative framework of organizational control. Accounting, organizations and society, 10(1), 35-50. https://doi.org/10.1016/0361-3682(85)90030-3

Foss, N. J., Pedersen, T., Reinholt Fosgaard, M., \& Stea, D. (2015). Why Complementary HRM Practices Impact Performance: The Case of Rewards, Job Design, and Work Climate in a Knowledge-Sharing Context. Human Resource Management, 54, 955-976. https://doi.org/10.1002/hrm.21649

Franco, L. M., Bennett, S., \& Kanfer, R. (2002). Health sector reform and public sector health worker motivation: a conceptual framework. Social Science \& Medicine, 54(8), 1255-1266. https://doi.org/10.1016/S0277-9536(01)00094-6

Frey, B. S. (1997). Not just for the money. Cheltenham: Edward Elgar Publishing.

Frey, B. S., \& Jegen, R. (1999). Motivation crowding theory: a survey of empirical evidence. Institute for Empirical Research in Economics, University of Zurich. 
Galletta, M., Portoghese, I., Fabbri, D., Pilia, I., \& Campagna, M. (2016). Empowering workplace and among healthcare professionals: The buffering role of job control. Acta Biomedica, 87(Suppl. 2), 61-69.

Gilbreath, B., Benson, P. (2004). The contribution of Supervisor Behaviour to Employee Psychological Well-Being. Work and Stress, 18(3), 255-266. https://doi.org/10.1080/02678370412331317499

Glisson, C. (2015). The Role of Organizational Culture and Climate in Innovation and Effectiveness. Human service organizations, management, leadership \& governance, 39(4), 245-250. https://doi.org/10.1080/23303131.2015.1087770

Gosseries, O., Demertzi, A., Ledoux, D., Bruno, M.-A., Vanhaudenhuyse, A., Thibaut, A., \& Schnakers, C. (2012). Burnout in healthcare workers managing chronic patients with disorders of consciousness. Brain Injury, 26(12), 1493-1499. https://doi.org/10.3109/02699052.2012.695426

Grandori, A. (2001). Organization and Economic Behavior. New York, Routledge. https://doi.org/10.4324/9780203160411

Grant, A., Dutton, J., \& Rosso, B. (2008). Giving commitment: Employee support programs and the prosocial sensemaking process. Academy of Management Journal, 51, 898-918. https://doi.org/10.5465/AMJ.2008.34789652

Guzzo, R. A., Jette, R. D., \& Katzell, R. A. (1985). The effects of psychologically based intervention programs on worker productivity: a meta-analysis. Personnel Psychology, 38, 275-291. https://doi.org/10.1111/j.1744-6570.1985.tb00547.x

Hammermann, A., \& Mohnen, A. (2014). The pric(z)e of hard work. Different incentive effects on non-monetary and monetary prizes. Journal of Economic Psychology, 43, 1-15. https://doi.org/10.1016/j.joep.2014.04.003

Hasselhorn, H. M., Tackenberg, P., \& Peter, R. (2004). Effort-reward imbalance among nurses in stable countries and in countries in transition. International Journal of Occupational And Environmental Health, 10(4), 401-408. https://doi.org/10.1179/oeh.2004.10.4.401

Herzberg, F. (1986). One more time: How do you motivate employees. Harvard Business Review.

Herzberg, F., Mausner, B., \& Snyderman, B. B. (1959). The motivation to work (2nd ed.). New York, NY: John Wiley.

Hibbard, J. H., Stockard, J., \& Tusler, M. (2003). Does publicizing hospital performance stimulate quality improvement efforts? Health Affairs, 22(2), 84-94. https://doi.org/10.1377/hlthaff.22.2.84

Hornby, P., \& Sidney, E. (1988). Motivation and Health Service Performance. Geneva: World Health Organization.

Jenkins, G. D. Jr., Mitra, A., Gupta, N., \& Shaw, J. D. (1998). Are financial incentives related to performance? A metaanalytic review of empirical research. Journal of Applied Psychology, 83, 777-787. https://doi.org/10.1037/0021-9010.83.5.777

Kaplan, S., Cortina, J., Ruark, G., LaPort, K., \& Nicolaides, V. (2014). The role of organizational leaders in employee emotion management: A theoretical model. The Leadership Quarterly, 25, 563-580. https://doi.org/10.1016/j.leaqua.2013.11.015

Kilfedder, C. J., Power, K. G., \& Wells, T. J. (2001). Burnout in psychiatric nurses. Journal of Advanced Nursing, 34(3), 383-396. https://doi.org/10.1046/j.1365-2648.2001.01769.x

Kolstad, J. R. (2011). How to make rural jobs more attractive to health workers. Findings from a discrete choice experiment in Tanzania. Health Economics, 20(2), 196-211. https://doi.org/10.1002/hec.1581

Koseoglu, G., Liu, Y., \& Shalley, E. C. (2017). Working with creative leaders: Exploring the relationship between supervisors' and subordinates' creativity. The Leadership Quarterly, 28(6), 798-811, https://doi.org/10.1016/j.leaqua.2017.03.002

Kuvaas, B., Buch, R., Weibel, A., Dysvik, A., \& Nerstad, C. (2017). Do intrinsic and extrinsic motivation relate differently to employee outcomes? Journal of Economic Psychology, 61, 244-258. https://doi.org/10.1016/j.joep.2017.05.004

Kvaløy, O., \& Schöttner, A. (2015). Incentives to motivate. Journal of Economic Behavior \& Organization, 116, 26-42. https://doi.org/10.1016/j.jebo.2015.03.012

Kwon, K., \& Rupp, D. (2013). High-performer turnover and firm performance: The moderating role of human capital investment and firm reputation. Journal of Organizational Behavior, 34, 129-150. 
https://doi.org/10.1002/job.1804

Lau, C. M., \& Roopnarain, K. (2014). The effects of nonfinancial and financial measures on employee motivation to participate in target setting. The British Accounting Review, 46(3), 228-247. https://doi.org/10.1016/j.bar.2014.02.006

Lawler, E. E. III. (1973). Motivation in work organizations. Monterey, California: Brooks/Cole Publishing Company.

Lee, J., \& Miller, D. (1999). People matter: Commitment to employees, strategy and performance in Korean $\begin{array}{llll}\text { firms. } & \text { Strategic } & \text { Management }\end{array}$ https://doi.org/10.1002/(SICI)1097-0266(199906)20:6<579::AID-SMJ37>3.0.CO;2-C

Liu, D., Jiang, K., Shalley, C., Keem, S., \& Zhou, J. (2016). Motivational mechanisms of employee creativity: A meta-analytic examination and theoretical extension of the creativity literature. Organizational Behavior and Human Decision Processes, 137, 236-263. https://doi.org/10.1016/j.obhdp.2016.08.001

Locke, E. A., Shaw, K., Saari, L., \& Latham, G. (1981). Goal-setting and task performance: 1969-1980. Psychological Bulletin, 90, 125-152. https://doi.org/10.1037/0033-2909.90.1.125

Lut, D. M. (2012). Connection between job motivation, job satisfaction and work performance in Romanian Trade Enterprises, Annals of "Dunarea de Jos" University of Galati Fascicle I. Economics and Applied Informatics, 3, 45-50

Markwell, A. L., \& Wainer, Z. (2009). The health and wellbeing of junior doctors: Insights from a national survey. Medical Journal of Australia, 191(8), 441-444.

Martínez-Íñigo, D., \& Totterdell, P. (2016). The mediating role of distributive justice perceptions in the relationship between emotion regulation and emotional exhaustion in healthcare workers. Work and Stress, 30(1), 26-45. https://doi.org/10.1080/02678373.2015.1126768

Mason, S., O'Keeffe, C., Carter, A., \& Stride, C. (2016). A longitudinal study of well-being, confidence and competence in junior doctors and the impact of emergency medicine placements. Emergency Medicine Journal, 33(2), 91-98. https://doi.org/10.1136/emermed-2014-204514

Mathieu, C., \& Babiak, P. (2016). Corporate psychopathy and abusive supervision: Their influence on employees' job satisfaction and turnover intentions. Personality and Individual Differences, 91, 102-106. https://doi.org/10.1016/j.paid.2015.12.002

Mathieu, C., Neumann, C. S., Hare, R. D., \& Babiak, P. (2014). A dark side of leadership: Corporate psychopathy and its influence on employee well-being and job satisfaction. Personality and Individual Differences, 59, 83-88. https://doi.org/10.1016/j.paid.2013.11.010

McAllister, D., \& Bigley, G. (2002). Work context and the definition of self: How organizational care influences organization-based self-esteem. Academy of Management Journal, 45, 894-904. https://doi.org/10.2307/3069320

McDonald, R., Harrison, S., Checkland, K., Campbell, S. M., \& Roland, M. (2007). Impact of financial incentives on clinical autonomy and internal motivation in primary care: ethnographic study. $B M J, 334$, 1357. https://doi.org/10.1136/bmj.39238.890810.BE

McVicar, A. (2003). Workplace stress in nursing: A literature review. Journal of Advanced Nursing, 44(6), 633642. https://doi.org/10.1046/j.0309-2402.2003.02853.x

Miller, D., \& Lee, J. (2001). The people make the process: Commitment to employees, decision making, and performance. Journal of Management, 27, 163-189. https://doi.org/10.1177/014920630102700203

Miller, D., Lee, J., Chang, S., \& Le Breton-Miller, I. (2009). Filling the institutional void: The social behavior and performance of family vs. non-family technology firms in emerging markets. Journal of International Business Studies, 40, 802-817. https://doi.org/10.1057/jibs.2009.11

Neal, A., Griffin, M. A., \& Hart, P. M. (2000). The impact of organizational climate on safety climate and individual behavior. Safety Science, 34(1-3), 99-109. https://doi.org/10.1016/S0925-7535(00)00008-4

Niedl, K. (1996). Mobbing and wellbeing: Economic and personnel development implications. European Journal of Work and Organizational Psychology, 5, 239-249. https://doi.org/10.1080/13594329608414857

Nielsen, K., \& Randall, R. (2012). The importance of employee participation and perceptions of changes in procedures in a teamworking intervention. Work Stress, 26(2), 91-111. 
https://doi.org/10.1080/02678373.2012.682721

Pankl, E., Theiss-White, D., \& Bushing, M. C. (2010). Recruitment, Development, and Retention of Information Professionals: Trends. Hershey (NY), Business Science Reference. https://doi.org/10.4018/978-1-61520-601-8

Park, K.-O., Wilson, M. G., \& Myung, S. L. (2004). Effects of social support at work on depression and organizational productivity. American Journal of Health Behavior, 28(5), 444-455. https://doi.org/10.5993/AJHB.28.5.7

Poissonnet, C. M., \& Véron, M. (2000). Health effects of work schedules in healthcare professions. Journal of Clinical Nursing, 9(1), 13-23. https://doi.org/10.1046/j.1365-2702.2000.00321.x

Prendergast, C. (1999). The provision of incentives in firms. Journal of Economic Literature, 37, 7-63. https://doi.org/10.1257/jel.37.1.7

Ray-Sannerud, B. N., Leyshon, S., \& Vallevik, V. B. (n.d.). Introducing routine measurement of healthcare worker's well-being as a leading indicator for proactive safety management systems based on Resilience Engineering. Procedia Manufacturing, 3, 319-326. https://doi.org/10.1016/j.promfg.2015.07.163

Rhoades, L., \& Eisenberger, R. (2002). Perceived organizational support: A review of the literature. Journal of Applied Psychology, 87, 698-714. https://doi.org/10.1037/0021-9010.87.4.698

Riggle, R., Edmondson, D., \& Hansen, J. (2009). A meta-analysis of the relationship between perceived organizational support and job outcomes: 20 years of research. Journal of Business Research, 62, 1027-1030. https://doi.org/10.1016/j.jbusres.2008.05.003

Rose, J., \& Glass, N. (2009). An investigation of emotional wellbeing and its relationship to contemporary nursing practice. Collegian, 16, 185-192. https://doi.org/10.1016/j.colegn.2009.08.001

Ryan, R. M., \& Deci, E. L. (2000). Intrinsic and Extrinsic Motivations: Classic Definitions and New Directions. Contemporary Educational Psychology, 25(1), 54-67. https://doi.org/10.1006/ceps.1999.1020

Rynes, S., Bartunek, J., Dutton, J., \& Margolis, J. (2012). Care and compassion through an organizational lens: Opening up new possibilities. Academy of Management Review, 37, 503-523.

Salmond, S., \& Ropis, P. E. (2005). Job stress and general wellbeing: A comparative study of medical-surgical and home care nurses. Medical Surgery Nursing, 14(5), 301-309.

Sancassiani, F., Campagna, M., Tuligi, F., Machado, S., Cantone, E., \& Carta, M. G. (2015). Organizational wellbeing among workers in mental health services: A pilot study. Clinical Practice of Epidemiology Mental Health, 11, 4-11. https://doi.org/10.2174/1745017901511010004

Schmidt, K. M., Fey, L., \& Thoma, C. (2017). Competition and incentives. European Economic Review, 98, 111-125. https://doi.org/10.1016/j.euroecorev.2017.06.012

Sebastiano, A., Belvedere, V., Grando, A., \& Giangreco, A. (2017). The effect of capacity management strategies on employees' well-being: A quantitative investigation into the long-term healthcare industry. 35, 563-573. https://doi.org/10.1016/j.emj.2016.12.001

Shortell, S. M., \& Kaluzny, A. D. (2006). Health care management: organization design and behavior (5th ed.). Clifton Park, NY: Delmar Learning. Behavior.

Singh, D., Negin, J., Otim, M., Orach, C., \& Cumming, R. (2015). The effect of payment and incentives on motivation and focus of community health workers: five case studies from low- and middle-income countries. Human Resources for Health, 13, 58. https://doi.org/10.1186/s12960-015-0051-1

Sun, N., Dong-Mei, L., Jing, M., Xiao-yu, W., Qin, C., Hong-li, F., \& Qun-hong, W. (2016). The correlation between quality of life and social support in female nurses. Journal of Clinical Nursing.

Suresh, P., Matthews, A., \& Coyne, I. (2013). Stress and stressors in the clinical environment: A comparative study of fourth-year student nurses and newly qualified general nurses in Ireland. Journal of Clinical Nursing, 22(5-6), 770-779.

Tepas, D. I., Barnes-Farrell, J. L., Bobko, N., Fischer, F. M., Iskra-Golec, I., \& Kaliterna, L. (2004). The impact of night work on subjective reports of well-being: An exploratory study of health care workers from five nations. Revista de Saúde Pública, 38, 26-31. https://doi.org/10.1590/S0034-89102004000700005

Tomo A., \& De Simone, S. (2017). Exploring Factors that Affect the Well-Being of Healthcare Workers. International Journal of Business and Management, 12(6), 49-61. https://doi.org/10.5539/ijbm.v12n6p49 
Tsai, Y. (2011). Relationship between Organizational Culture, Leadership Behavior and Job Satisfaction. BMC Health Service Research, 11, 98-106. https://doi.org/10.1186/1472-6963-11-98

Tuisku, K., Virtanen, M., De Bloom, J., \& Kinnunen, U. (2016). Cultural leisure activities, recovery and work engagement among hospital employees. Industrial Health, 54(3), 254-262. https://doi.org/10.2486/indhealth.2015-0124

Vakkayil, J., Della Torre, E., \& Giangreco, A. (2017). "It's not how it looks!” Exploring managerial perspectives on employee wellbeing. European Management Journal, 35, 548-562. https://doi.org/10.1016/j.emj.2016.12.002

Van De Voorde, K., Paauwe, J., \& Van Veldhoven, M. (2012). Employee well-being and the HRM-organizational performance relationship: A review of quantitative studies. International Journal of Management Reviews, 14, 391-407. https://doi.org/10.1111/j.1468-2370.2011.00322.x

VandeWalle, D., Ganesan, S., Challagalla, G. N., \& Brown, S. P. (2000). An integrated model of feedback-seeking behavior: disposition, context, and cognition. Journal of Applied Psychology, 85(6), 996. https://doi.org/10.1037/0021-9010.85.6.996

Victor, B., \& Cullen, J. (1988). The organizational bases of ethical work climates. Administrative Science Quarterly, 33, 101-125. https://doi.org/10.2307/2392857

Vroom, V. (1964). Work and motivation. New York, NY: John Wiley.

Wallace, J. E., Lemaire, J. B., \& Ghali, W. A. (2009). Physician wellness: A missing quality indicator. Lancet, 374(9702), 1714-1721. https://doi.org/10.1016/S0140-6736(09)61424-0

Wayne, S., Shore, L., \& Liden, R. (1997). Perceived organizational support and leader-member exchange: A social exchange perspective. Academy of Management Journal, 40, 82-111. https://doi.org/10.2307/257021

Woolhandler, S., Ariely, D., \& Himmelstein, D. U. (2012). Why pay for performance may be incompatible with quality improvement. BMJ., 345(7870), e5015. https://doi.org/10.1136/bmj.e5015

Yildirim, A., \& Yildirim, D. (2007). Mobbing in the workplace by peers and managers: Mobbing experienced by nurses working in healthcare facilities in Turkey and its effect on nurses. Journal of Clinical Nursing, 16(8), 1444-1453. https://doi.org/10.1111/j.1365-2702.2006.01814.x

Zakaria, M., Kamaruzaman Abdulatiff, N., \& Alia, N. (2014). The Role of Wellbeing on Performance in Services Sector. Procedia - Social and Behavioral Sciences, 164, 358-365. https://doi.org/10.1016/j.sbspro.2014.11.088

\section{Copyrights}

Copyright for this article is retained by the author(s), with first publication rights granted to the journal.

This is an open-access article distributed under the terms and conditions of the Creative Commons Attribution license (http://creativecommons.org/licenses/by/4.0/). 